\title{
血漿アルブミン酸化還元動態とタンパク質栄養
}

\section{The Oxidized/Reduced State of Plasma Albumin and Protein Nutrition}

\section{桑波田 雅士}

Masashi Kuwahata

\author{
京都府立大学大学院生命環境科学研究科栄養科学 \\ Department of Nutrition Science, Graduate School of Life \\ and Environmental Sciences, Kyoto Prefectural University
}

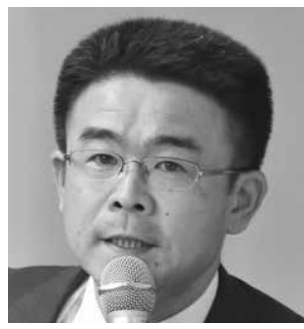

血漿アルブミン濃度は、世界中で最も広く利用されている栄養りスクマーカーである。外科領域に抏 いても低アルブミン血症は、術後生存率や合併症の発症率と関連することが報告されている。アルブミ ン分子は、アミノ末端から 34 番目に位置するシステイン残基の側鎖の修飾状態から、還元型と酸化型 に大別される。そしてアルブミンが有している栄養成分や薬剤等の輸送能、膠質浸透圧や抗酸化作用な どの生理機能にも還元型と酸化型で差が生じると考えられている。栄養状態が良好な健常者の場合、70 〜 80\%の血漿アルブミンが還元型、残りが酸化型として存在している。しかしながら様々な慢性疾患の 患者では、病態の進行とともに血漿アルブミン還元型比率は低下し、酸化型比率が上昇していることが 報告されている。

一方、我々が実施した動物実験では、健常ラットに対する食事制限が、血漿アルブミン還元型比率を 低下させ、酸化型比率を上昇させることを明らかにした。すなわち疾病が存在しない状態においても、 食事摂取状況がアルブミン酸化還元動態に影響を及ぼすことを示唆した。さらに血漿アルブミン酸化還 元比率の変化は、血漿アルブミン濃度の変化よりも早期に検出され、より鋭敏な食事評価マーカーと成 り得る可能性を見出した。

アルブミン酸化還元動態に及ぼす影響は、とりわけタンパク質制限食摂取時に顕著であった。乳力ゼ インをタンパク質源とした実験では、肝臓におけるアルブミン合成能と血漿アルブミン還元型比率に相 関が認められたことから、タンパク質摂取不足に伴うアルブミン還元型比率の低下は、肝臟におけるア ルブミン合成能の低下を反映していると考えられた。さらに、異なるタンパク質源を用いて調整した低 タンパク質食を攝取させた場合には、アルブミン酸化還元動態に及ぼす影響が異なることを明らかにし た。すなわち食事タンパク質の質も重要であることを示唆し、本実験条件下では、少なくとも食事タン パク質に含まれる含硫アミノ酸シスチンの含有量が、血漿アルブミン酸化還元動態に大きく影響する可 能性を見出している。

アルブミンは血漿中に最も多量に存在するタンパク質であり、この分子の酸化還元動態は、生体に様々 な影響を及ぼすことが予想される。今後、濃度変化だけでなく、アルブミン酸化還元動態を考慮した栄 養管理も重要となるであろう。 